\title{
System Efficiency of Proton Exchange Membrane Fuel Cell for Emergency Power Supply System
}

\author{
Seung-Won Jeon, Jung-Yup Kim, Su-Gak Lee \\ Korea Institute of Civil Engineering and Building Technology \\ Baekgok-ri, Mado-myeon, Hwaseong-si, Gyeonggi-do, 18544, Republic of Korea \\ seungwonjeon@kict.re.kr; jykim1@kict.re.kr; wm8284@kict.re.kr
}

\section{Extended Abstract}

Proton exchange membrane fuel cells (PEMFCs) have been widely used in various applications due to its advantages of high power density, rapid start-up, and high efficiency [1]. Especially, the PEMFC can be applied in an emergency power supply system such as high-rise building and complex facilities. The emergency power supply is very important in the high-rise building and complex facilities because a normal source of power can be failed during urgent disaster situations.

There have been a lot of advances in the development of low temperature PEMFC. Recently, to overcome the problem of water flooding, high temperature PEMFC has been highlighted [2-4]. However, very large amount of water vapor is required to humidify PEMFC at the elevated temperature because saturation water vapor pressure increases exponentially with temperature. Therefore, it is necessary to analyze the performance of the high temperature PEMFC under various humidity conditions in terms of system efficiency.

There has been a lot of studies to investigate the effect of temperature and relative humidity on the performance of PEMFC [5-7]. In addition, limited studies have been performed by considering balance of plant (BOP) components and combined power and heat production (CHP) for PEMFC [8-10]. However, it is required to evaluate the system efficiency more accurately by considering the thermal power for preheating and humidification, and the compression work for BOP components. In this study, to overcome the limitations of the previous study, three-dimensional computational fluid dynamics simulation was conducted. A unit cell with serpentine flow field was simulated, and compression work was considered for the BOP component together with the heat for preheating and humidification. The operating conditions were optimized using response surface methodology by considering both fuel cell output and system efficiency, and the amount of each energy component was analyzed. In addition, the effects of operating parameters such as temperature, relative humidity, and stoichiometric ratio on fuel cell power, system efficiency, and each energy component were investigated.

As a result, the optimal operating conditions were $90.6{ }^{\circ} \mathrm{C}$ and $100.0 \%$ for the temperature and relative humidity, respectively, and 0.27 for stoichiometric ratio. In addition, at the optimal condition, the power output was $1.28 \mathrm{~W}$ and the system efficiency was $15.8 \%$. The optimal condition showed a comparatively high system efficiency with allowable power output. In addition, the power output increased with the operating temperature, but the system efficiency decreased significantly because of exponentially increasing saturation vapor pressure and thermal energy for preheating/humidification. The system efficiency can be more effectively improved by increasing relative humidity rather than increasing operating temperature, because the ionic conductivity of the membrane is greatly affected by the relative humidity.

\section{Acknowledgements}

This work was supported by the National Research Council of Science \& Technology (NST) grant by the Korea government (MSIP) (No. CRC-16-02-KICT) 


\section{References}

[1] Y. Wang, K. S. Chen, J. Mishler, S. C. Cho, and X. C. Adroher, "A review of polymer electrolyte membrane fuel cells: Technology, applications, and needs on fundamental research," Appl. Energy, vol. 88, no. 4, pp. 981-1007, 2011.

[2] J. Zhang et al., "High temperature PEM fuel cells," J. Power Sources, vol. 160, no. 2 SPEC. ISS., pp. 872-891, 2006.

[3] A. Chandan et al., "High temperature (HT) polymer electrolyte membrane fuel cells (PEMFC) - A review," $J$. Power Sources, vol. 231, pp. 264-278, 2013.

[4] S. Bose, T. Kuila, T. X. H. Nguyen, N. H. Kim, K. Lau, and J. H. Lee, "Polymer membranes for high temperature proton exchange membrane fuel cell: Recent advances and challenges," Prog. Polym. Sci., vol. 36, no. 6, pp. 813843, 2011.

[5] J. Zhang, Y. Tang, C. Song, X. Cheng, J. Zhang, and H. Wang, "PEM fuel cells operated at 0\% relative humidity in the temperature range of 23-120??C," Electrochim. Acta, vol. 52, no. 15, pp. 5095-5101, 2007.

[6] J. Zhang et al., "PEM fuel cell relative humidity (RH) and its effect on performance at high temperatures," Electrochim. Acta, vol. 53, no. 16, pp. 5315-5321, 2008.

[7] C. Song et al., "PEM fuel cell reaction kinetics in the temperature range of $23-120^{\circ}$ C," Electrochim. Acta, vol. 52, no. 7, pp. 2552-2561, 2007.

[8] H. S. Han, C. Cho, S. Y. Kim, and J. M. Hyun, "Performance evaluation of a polymer electrolyte membrane fuel cell system for powering portable freezer," Appl. Energy, vol. 105, pp. 125-137, 2013.

[9] N. Zuliani and R. Taccani, "Microcogeneration system based on HTPEM fuel cell fueled with natural gas: Performance analysis," Appl. Energy, vol. 97, pp. 802-808, 2012.

[10] E. Jannelli, M. Minutillo, and A. Perna, "Analyzing microcogeneration systems based on LT-PEMFC and HTPEMFC by energy balances," Appl. Energy, vol. 108, pp. 82-91, 2013. 